\title{
Food intake and anthropometric evaluation in school-aged children of Buenos Aires
}

\author{
Irina Kovalskys ${ }^{a}$, M.D., Paula Indart Rougier ${ }^{a}$, B.S., María Paz Amigo ${ }^{a}$, B.S., \\ María José De Gregorio , B.S., Cecile Rausch Herscovici ${ }^{a}$, M.D., and Marcela Karner ${ }^{a}$, B.S.
}

\begin{abstract}
Introduction. The main objectives of this study were to analyze food intake and to determine the prevalence of overweight and obesity in schoolaged children.

Population and Methods. Fifth-grade children from 80 randomly-selected public schools from the Buenos Aires metropolitan area were included. Data on food intake were collected using a 24-hour recall period and frequency of weekly consumption. Data on weight and height were also collected.

Results. The sample was made up of 1673 children (854 girls and 819 boys), with an average age of 10.9 years old. The average calorie intake was $2316 \mathrm{kcal} /$ day $( \pm 888)$ with an adequacy ratio of $115.8 \%$ in relation to the dietary reference intake. Of the total assessed children, $21.3 \%$ was overweight and $14.3 \%$ was obese. Mean intake of dietary fiber was $9 \mathrm{~g} /$ day (dietary reference intake: $28 \mathrm{~g} /$ day, $32.1 \%$ of adequacy). Only $2 \%$ of children complied with the recommended intake of vegetables and $17 \%$, with the recommended intake of fruit. The most frequently consumed high calorie density foods were: soft drinks/juices, candies, sweet cookies and high fat seasonings and dressings.

Conclusions. The high calorie intake, together with the prevalence of overweight and obesity in the studied population, justifies the need to implement nutrition education programs targeted at encouraging a healthier diet.

Key words: intake, school-aged children, nutrition,
\end{abstract} overweight, obesity.

Nutrition, Obesity and Physical Activity Committee. International Life Sciences Institute (ILSI) Argentina.

b. Department of Anthropology, Universidad de Buenos Aires. Buenos Aires, Argentina.

E-mail:

Irina Kovalskys, M.D.: ikovalskys@ilsi.org.ar

Funded by:

ILSI Argentina.

Conflict of Interest:

None.

Received: 05-23-2012 Accepted: 08-22-2012 the main factors associated with obesity and adult chronic diseases. ${ }^{1,2}$ In ents and micronutrients during the different stages of childhood are extremely important to define health policies and programs and to build the bases for dietary reference intakes.

Increased calorie intake is one of addition, a progressive impairment of food quality, with an increased percentage of saturated fat intake and a reduced consumption of fruit and vegetables, seems to have become the generalized modality of food intake of this new age. ${ }^{3}$

The analysis of food intake characteristics of each population and its association with obesity is one of the research priorities of the World Health Organization (WHO).

A lack of data at the population level on food intake and local consumption patterns in Argentinean children have led to carrying out this study whose objectives are the following:

\section{Primary objective}

- To analyze and evaluate food intake and to determine the prevalence of overweight and obesity in school-aged children.

\section{Secondary objectives}

- To estimate nutrient composition of diets and compare values obtained versus the dietary reference intakes (DRIs) by age and gender.

- To determine the frequency of weekly consumption of high calorie density foods, fruit and vegetables.

\section{POPULATION AND METHODS}

This was a descriptive, cross-sectional study with a random selection sample representing fifth-grade children from public schools from the Buenos Aires metropolitan area (City of Buenos Aires and Buenos Aires suburbs). Data were collected from June to December, 2005.

In order to cover the entire socioeconomic spectrum, we systematically selected, using a random start and population odds ratios, 16 census 
fractions in the City of Buenos Aires, based on the 1991 National Population and Housing Census, ${ }^{4}$ and 64 cities in greater Buenos Aires, based on the 2001 National Population and Housing Census. ${ }^{5}$ In both cases, census units were arranged based on overcrowded households (proxy measure for estimating the socioeconomic level). Eighty public primary schools were randomly selected from these fractions and cities according to the lists provided by the corresponding government agencies. Such design guarantees a sample that represents the Buenos Aires metropolitan area, reproduces the socioeconomic profile of the population under study in a proportional manner, and may be processed using a statistical software created specifically for simple random samples.

Fifth-grade children were studied after their parents had given their written consent for participation in this research.

Children that indicated having a chronic or acute condition that may have affected their nutritional status at the time of the assessment were excluded. Children indicating to have modified their food consumption patterns as a result of a pre-existing disease were also excluded.

For the assessment of food intake, two instruments were used: a 24 hour recall period and frequency of weekly consumption.

\section{Twenty-four hour recall period}

The objective of the 24 hour recall period was to help the child remember all the foods and beverages he/she had the day before. This survey was administered by nutritionists, who used visual samples of foods, 6 replicas of food and homemade measurement instruments (plate, glass, etc.) to recall and accurately describe all the foods and beverages consumed in the prior 24 hours.

Surveys were completed on Tuesdays, Wednesdays, and Thursdays to avoid including data from the weekends.

Collected data were entered into a database and analyzed using a software especially designed according to the table of chemical composition prepared by the Experimental and Applied Endocrinology Center (Centro de Endocrinología Experimental y Aplicada, CENEXA), ${ }^{7}$ which determined the content of calories and macronutrients of foods. Values were then compared to DRIs. ${ }^{8,11}$

\section{Frequency of weekly consumption}

We used a questionnaire based on the list of foods and beverages dictated by local consumption patterns and that may be strongly associated with the development of overweight and obesity. This list included both healthy foods (fruit and vegetables) and high calorie density foods (burgers/hot dogs, breaded chicken/fish, choripán (a sandwich prepared with bread and highly seasoned pork sausage), pizza/empanada (a turnover of filled pastry), sweet cookies, candies (with no chocolate), snacks/slight meals, soft drinks/juices, chocolate, cakes/pastries, fried foods, butter/high fat seasonings and dressings). We also determined the categories for establishing how often children consumed such foods and beverages over the week.

For the assessment of fruit and vegetable consumption, we compared daily intake with the recommendations of the Food Guidelines for Argentinean Population ("eat five helpings of fruit and vegetables a day"). ${ }^{12}$ Based on this recommendation, the consumption of two or more helpings of fruit a day was considered "adequate", at least one helping a day was considered "acceptable", and no daily consumption was considered "inadequate". For vegetables (raw or cooked), the consumption of two or more helpings a day was regarded as "adequate", at least one daily helping was regarded as "acceptable" and no daily consumption was regarded as "inadequate".

Both surveys ( 24 hour recall period and frequency of weekly consumption) were administered by 20 B.S. in Nutrition with specialization in anthropometrics, who were previously trained in the administration of surveys and the anthropometric assessment instruments to accurately estimate food and beverage quantities and anthropometric measurements. Each child was interviewed during 40 minutes in average.

\section{Anthropometry}

CAM portable scales (Buenos Aires, Argentina) were used to measure weight and height, with a resolution of up to 100 grams, together with SECA wall removable Bodymeter 208 stadiometers (Hamburg, Germany), with a resolution of up to 1 millimeter. Based on these data, the body mass index (BMI) was calculated and compared to WHO's 2007 standards (overweight: z-score $>1$ SD, and obesity: z-score $>2$ SD). ${ }^{13}$ For the anthropometric analysis, only children aged 10-11.9 years old were considered; for this reason, the sample was made up of 1588 children $(817 \mathrm{fe}$ males and 771 males).

\section{Statistical processing}

Data were processed using the statistical software SPSS 10.0. Anthropometric data were 
analyzed by calculating mean and dispersion measures (standard deviation, SD) with the software Epi Info version 6.04 (1996, Centers for Disease Control-WHO, Atlanta, USA). Comparisons by gender and weight category were made with a t test for risk difference.

Statistical significance was established at $p<0.05$. For the study of calorie and macronutrient intake, mean and SD values were calculated, and a percentile distribution for the sample was performed; for this, cut-off points for the $25^{\text {th }}, 50^{\text {th }}$ and $75^{\text {th }}$ percentiles (Pc25, Pc50 and Pc75) were estimated.

\section{RESULTS}

The sample was made up of 1673 children (854 girls and 819 boys), with an average age of 10.9 years old. Ninety five percent of children was 10-11 years old, and only $5 \%$ was 12 years old.

Table 1 shows the characteristics of the sample evaluated and the prevalence of overweight and obesity by gender. These results are stated for the $95 \%$ of the population $(n=1588)$. No significant differences were observed in the total sample results $(\mathrm{n}=1673)$.

Table 2 shows calorie intake and nutrient composition by gender, stated using mean, SD and percentile values. It also includes the adequacy ratio of DRIs for the sample mean.

The analysis of macronutrient intake indicated that it is harmoniously distributed; at a mean population level, with a calorie intake of $53 \%$ of carbohydrates, $15 \%$ of proteins, and $32 \%$ of fat.

Males consume 187 and $199 \mathrm{kcal}$ more than females in the $50^{\text {th }}$ and $75^{\text {th }}$ percentiles, respectively. In the Pc50, girls consume $2091 \mathrm{kcal}$, while boys consume $2278 \mathrm{kcal}$, and in the Pc75, girls and boys consume 2716 and $2915 \mathrm{kcal}$, respectively. The percentages of energy from carbohydrates, proteins and fat are stable and independent from the total calorie value.

The mean cholesterol intake is $295.8 \mathrm{mg} /$ day.

In terms of fruit and vegetables daily consumption according to the recommendations of the Food Guidelines for Argentinean Population, ${ }^{12}$ we found that, for the studied population, consumption was adequate in $17 \%$, acceptable in $26 \%$, and inadequate in $57 \%$. In relation to veg-

TABLE 1. Description of sample and prevalence of overweight and obesity for the total population and by gender

\begin{tabular}{lccc}
\hline & Total $(\mathbf{n}=\mathbf{1 5 8 8})$ & Females $(\mathbf{n}=\mathbf{8 1 7})$ & Males $(\mathbf{n}=\mathbf{7 7 1})$ \\
\hline Age $($ years $)$ & $10.9( \pm 0.4)^{*}$ & $10.9( \pm 0.4)^{*}$ & $10.9( \pm 0.4)^{*}$ \\
Weight $(\mathrm{kg})$ & $39.2( \pm 9.5)^{*}$ & $39.1( \pm 9.4)^{*}$ & $39.3( \pm 9.6)^{*}$ \\
Height $(\mathrm{cm})$ & $143.1( \pm 6.9)^{*}$ & $143.5( \pm 7.0)^{*}$ & $142.6( \pm 6.8)^{*}$ \\
BMI $\left(\mathrm{kg} / \mathrm{m}^{2}\right)$ & $19.01( \pm 3.55)^{*}$ & $18.83( \pm 3.50)^{*}$ & $19.18( \pm 3.64)^{*}$ \\
Overweight $(\%)^{a}$ & 21.3 & 21.1 & 21.5 \\
Obesity $(\%)^{\mathrm{b}}$ & 14.3 & $10.6^{* *}$ & $17.9^{* *}$ \\
\hline
\end{tabular}

** Mean (standard deviation), ** Significant difference $\mathrm{p}<0.01$ by gender.

a. Z-score > 1 SD. WHO 2007; b. Z-score > 2 SD. WHO 2007.

TABLE 2. Data on calorie intake and nutrient composition by gender, expressed using mean, standard deviation (SD) and percentile values. Adequacy ratio in relation to DRI (comparing mean population values)

\begin{tabular}{|c|c|c|c|c|c|c|c|c|c|c|c|}
\hline \multirow{3}{*}{$\begin{array}{l}\text { Energy/ } \\
\text { Nutrient }\end{array}$} & \multirow{3}{*}{ Mean } & \multirow{3}{*}{ SD } & \multicolumn{4}{|c|}{ Total $(n=1673)$} & \multirow{3}{*}{$\begin{array}{c}\text { Adequacy } \\
\%\end{array}$} & \multicolumn{2}{|c|}{$\begin{array}{l}\text { Females } \\
(n=854)\end{array}$} & \multicolumn{2}{|c|}{$\begin{array}{l}\text { Males } \\
(n=819)\end{array}$} \\
\hline & & & & Percentile & & DRI* & & Mean & SD & Mean & SD \\
\hline & & & 25 & 50 & 75 & & & & & & \\
\hline $\begin{array}{l}\text { Total energy } \\
\text { (kcal/d) }\end{array}$ & 2316 & 888 & 1691.8 & 2175.7 & 2829.8 & 2000 & 115.8 & 2239 & 872 & 2396 & 898 \\
\hline $\begin{array}{l}\text { Carbohydrates } \\
(\mathrm{g} / \mathrm{d})\end{array}$ & 307 & 120 & 223.1 & 291.4 & 368.2 & $225-325(275)$ & 111.6 & 297.5 & 118 & 316 & 121.3 \\
\hline Proteins $(\mathrm{g} / \mathrm{d})$ & 88 & 40.1 & 59.8 & 82.2 & 111.1 & $50-75(62.5)$ & 140.8 & 84.7 & 40 & 92 & 40 \\
\hline Total lipids (g/d) & 84 & 44.9 & 51.1 & 76.5 & 107.1 & $55-77.7(66.35)$ & 126.6 & 81.3 & 43.2 & 86.8 & 46.5 \\
\hline Fiber $(\mathrm{g} / \mathrm{d})$ & 9 & 6.1 & 4.6 & 8 & 12.2 & 28 & 32.1 & 8.5 & 5.6 & 9.6 & 6.5 \\
\hline
\end{tabular}

* Food and Nutrition Board. Institute of Medicine. National Academy of Sciences.

DRI: dietary reference intake. 
etables, consumption was adequate only in $2 \%$, acceptable in $12 \%$, and inadequate in $86 \%$ of the studied children.

Table 3 shows the frequency of weekly consumption of high calorie density foods.

\section{DISCUSSION}

This study reveals that the average calorie intake in children aged 10-12 years old is $2316 \mathrm{kcal} /$ day. The mean calorie value is $15.8 \%$ higher than the recommendations. Approximately $25 \%$ of the population consumes $2829.8 \mathrm{kcal}$ or more, $40 \%$ higher than recommended (Pc75). In the studied population, overweight (including obesity) had an incidence of $35.6 \%$. Food distribution is harmonious, i.e., it is made up of an adequate proportion of carbohydrates, proteins and fat. However, with an increased calorie intake, absolute values in grams per day are above the recommendations. The rate of adequacy of fruit and vegetable consumption was really low, which translates into a suboptimal consumption of fiber in grams/day $(\mathrm{X}=9 \mathrm{~g} / \mathrm{d}, \mathrm{DRI}=28 \mathrm{~g} / \mathrm{d})$.

The National Survey on Nutrition and Health in Argentina (ENNyS, for its acronym in Spanish), conducted in 2005 in 10 year old girls, also found a harmonious distribution of macronutrients. The ENNyS also indicated that the consumption of fruit and vegetables among 10 year old girls, both at a national and regional level, was remarkably lower than the recommendations of the Food Guidelines for Argentinean Population. ${ }^{14}$

Dietary reference intakes, which are under continuous evaluation, are generated based on studies conducted in developed countries. For our study, we selected the DRIs for the USA population to be used as reference, since these are the DRIs most used in population studies. Although both in this study and in most publications it has been observed that males have a higher calorie and macronutrient intake, this DRI does not make a difference between males and females.

Other studies in children in this age group have reported a calorie intake similar to that found in this population. In 1996, Rolland-Cachera found in France that 10 year old children had a calorie intake of $2200 \mathrm{kcal} /$ day. ${ }^{15}$ Huang et al. (USA) established that the mean calorie intake was $1817( \pm 15) \mathrm{kcal}$, and this is consistent with the Madrid Nutrition Survey held in 2001-2002 (1905 kcal \pm 337$).{ }^{16}$ We have not found prior publications on the calorie intake in this age group in Argentina, but we found a Chilean reference from 2010 that indicates that the mean calorie intake in 11 year old children is $2135 \mathrm{kcal} /$ day, with a similar distribution to that of children in Buenos Aires. ${ }^{17}$

Overweight and obesity rates in the studied population demonstrate the importance of analyzing the total calorie intake in the diet of the pediatric population.

A total of $50 \%$ of the population under analysis had a carbohydrate, protein and fat intake higher than the dietary reference intake for their age (carbohydrates: DRI $=275 \mathrm{~g} / \mathrm{d}$, $\mathrm{X}=307 \mathrm{~g} / \mathrm{d}$; proteins: $\mathrm{DRI}=75 \mathrm{~g} / \mathrm{d}, \mathrm{X}=88 \mathrm{~g} / \mathrm{d}$; fat: DRI $=66.6 \mathrm{~g} / \mathrm{d}, X=84 \mathrm{~g} / \mathrm{d}$ ).

TABLE 3. Frequency of weekly consumption of high calorie density foods for the total population $(n=1673)$

\begin{tabular}{|c|c|c|c|c|}
\hline \multirow{2}{*}{$\begin{array}{l}\text { High calorie density } \\
\text { food or groups } \\
\text { of food }\end{array}$} & \multicolumn{4}{|c|}{ Frequency of weekly consumption (\%) } \\
\hline & Never & Once a week & Two-four times a week & Once a day or more \\
\hline Burgers/hot dogs & 47 & 32 & 20 & 1 \\
\hline Breaded chicken/fish & 44 & 29 & 26 & 1 \\
\hline Choripán* & 69 & 26 & 5 & 0 \\
\hline Pizzas/Empanadas & 17 & 45 & 37 & 1 \\
\hline Sweet cookies & 14 & 17 & 43 & 26 \\
\hline Candies (no chocolate) & 15 & 14 & 38 & 33 \\
\hline Snacks/slight meals & 44 & 20 & 26 & 10 \\
\hline Soft drinks/juices & 3 & 4 & 20 & 73 \\
\hline Chocolate & 25 & 22 & 38 & 15 \\
\hline Cakes/pastries & 25 & 38 & 29 & 8 \\
\hline Fried food & 18 & 30 & 49 & 3 \\
\hline $\begin{array}{l}\text { Butter/high fat seasonings } \\
\text { and dressings }\end{array}$ & 24 & 18 & 41 & 17 \\
\hline
\end{tabular}

*A sandwich prepared with bread and chorizo (highly seasoned pork sausage). 
In terms of food quality in this population, we found that the daily fat and carbohydrate intake is consistent with a high consumption of sweet cookies, candies, soft drinks/juices and high fat seasonings and dressings. In particular, we found a relevant frequency of consumption of sweetened drinks in the studied population, with $73 \%$ of children drinking soft drinks and concentrated juices once or more times a day. In our study, this finding was not related to the BMI or the displacement of other food. However, in the international literature, we found several studies that relate the consumption of sweetened beverages with overweight and obesity. ${ }^{18}$

The low consumption of fruit, vegetables and dietary fiber observed in our study is consistent with the global trend. Publications on this subject indicate that it is associated with their cost, the difficulty concerning their preparation, having less time available for cooking and competition with other industrialized products. ${ }^{19}$ The association between the low consumption of fruit and vegetables and childhood overweight has been demonstrated by several authors, ${ }^{20}$ in addition to the relation between the low consumption of fiber and non-transmissible chronic diseases. Findings in this study are alarming enough to encourage future interventions in this regard.

The relation between intake and health has been explored in several reports, but most of them are from countries with a feeding pattern that depends on their culture, as in the case of USA, where products like ice-cream, burgers, soft drinks and salty snacks are strongly related to overweight and a low nutrient intake during childhood and adolescence..$^{21}$ In Argentina, however, and in spite of culture globalization, it appears that cookies, high fat pastries and breads, and beverages are the products that most fat and sugar contribute to diet. ${ }^{22}$ A recent local publication including information on South American countries highlighted the importance of the environment for favoring a healthy diet and the need to perform local studies to establish intake patterns and our own interventions targeted at putting a halt on obesity. ${ }^{23}$

No linear relation between energy intake and overweight at an individual level has been established in this study, but it is worth underscoring the high prevalence of overweight and obesity that we have found.

In this age group, intake requirements may vary by gender and even by the degree of pubertal development.
This study did not include a food group analysis, which may have been interesting to observe diet composition, it did not look into any aspect related to eating habits, such as having breakfast, either.

The instrument used for measuring food and beverage consumption provides limited information because it refers to a general mode of eating, but does not allow to analyze volume, and it focuses only on the intake during week days. In order to avoid bias by using non-comparable days, this instrument has the limitation of not reporting information representative of weekends.

The methodology used to measure intake in population studies is still a controversial issue for most investigators who focus their work on intake in children. ${ }^{24,25}$ Authors like Rockett et al., who have conducted a thorough assessment of available methods to measure intake in adolescents, have concluded that there are few validated and reproducible studies, and therefore, no ideal method is yet available (i.e., short, easily administered, low cost and accurate). ${ }^{26}$ In this regard, Sidossi states that, to this date, there is no ideal method and that available validated methods (24 hour recall period and frequency of weekly consumption) together with a software for establishing food composition are acceptably reliable for the analysis of dietary intake. ${ }^{27}$ This is clearly a scientific field that is still under continuous development. Our study provides experience on the use of a validated method that allows to compare the results obtained with those of other Argentinean populations and of other similar age groups in the future.

The modality of having our own population sample and performing a percentile distribution of intake allowed us to analyze the studied population in terms of their mean value and also their minimum and maximum values.

This is the first study that provides information on the intake of 10-12 years old children in the metropolitan area of Buenos Aires. We believe that this information will enable future applications, such as:

1. To provide information for establishing national dietary reference intakes.

2. To help planning prevention programs to fight obesity and other non-transmissible chronic diseases.

3. To allow the implementation of nutrition education programs that will favor a healthier diet. 


\section{CONCLUSIONS}

The results of this investigation (a high overweight and obesity prevalence and an excessive calorie intake in up to $50 \%$ of the population) warrant the urgent need to work on children's eating habits since their early stages of development based on scientific information.

\section{Acknowledgments}

We would like to thank the General Schools Department of the city of Buenos Aires and the province of Buenos Aires, and especially to the principals and teachers, who opened the doors of their schools and classrooms because they trusted that the community would be the final target of this health research. We would also like to thank the children who, with excitement and patience, have granted us their precious study and leisure time.

\section{REFERENCES}

1. Singh AS, Mulder C, Twisk JW, van Merchelen W, et al. Tracking of childhood overweight into adulthood: a systematic review of the literature. Obes Rev 2008;9(5):474-88.

2. Giskes K, Kamphiuis CB, van Lenthe FJ, Kremer SS, et al. A systematic review of associations between environmental factors, energy and fat intakes among adults: is there evidence for environments that encourage obesogenic dietary intakes? Public Health Nutr 2007;10(10):1005-17.

3. Aranceta Bartrina J, Serra-Majem L, Pérez-Rodrigo C, et al. Nutrition risk in the child and adolescent population of the Basque country: the enKid Study. Br J Nutr 2006;96(Suppl1):S58-66.

4. INDEC, CNPV. Censo Nacional de Población y Vivienda, Ministerio de Economía, República Argentina. 1991.

5. INDEC, CNPVH. Censo Nacional de Población, Hogares y Viviendas, Ministerio de Economía. República Argentina. 2001.

6. Vásquez M, Witriw A. Modelos visuales de alimentos y tablas de relación peso/volumen. Buenos Aires: Universidad de Buenos Aires; 1997.

7. Mazzei M, Pachulu M. Tabla de Composición Química de los Alimentos CENEXA, Buenos Aires: CENEXA (Centro de Endocrinología Experimental Aplicada. UNLP-CONICET) - FEIDEN (Fundación para la promoción de la Educación y la Investigación en Diabetes y Enfermedades de Nutrición); 1995.

8. IOM, I.O.M. Dietary reference intakes for energy, carbohydrate, fiber, fat, fatty acids, cholesterol, protein, and amino acids (macronutrients). F.a.N. Board, Editor. Washington, DC: The National Academies; 2002.

9. IOM, I.O.M. Dietary reference intakes for calcium, phosphorus, magnesium, vitamin D, and uoride. F.a.N. Board. Washington, DC: The National Academies; 1997.

10. IOM, I.O.M. Dietary reference intakes for thiamin, riboavin, niacin, vitaminB6, folate, vitamin B12, pantothenic acid, biotin, and choline. F.a.N. Board. Washington, DC: The National Academies; 2000.

11. IOM, I.O.M. Dietary reference intakes for vitamin A, vitamin $\mathrm{K}$, arsenic, boron, chromium, copper, iodine, iron, manganese, molybdenum, nickel, silicon, vanadium, and zinc. F.a.N. Board, Editor. Washington, DC: The National Academies; 2001.

12. AADyND, et al. Guías alimentarias para la población argentina. Manual de multiplicadores. Buenos Aires, Argentina; 2005.

13. WHO. WHO Child growth standards. 2007. 2007; available at: http://www.who.int/growthref/who2007_bmi_ for_age/en/index.html.

14. Encuesta Nacional de Nutrición y Salud (ENNyS). Documento de Resultados. Ministerio de Salud de la Nación; 2007.

15. Rolland-Cachera M, Deheeger M, Bellisle F. Nutritional changes between 1978 and 1995 in 10 year old French children. Int J Obesity 1996;20(4):105-53.

16. Díez-Gañán L, et al. Encuesta de Nutrición Infantil de la Comunidad de Madrid. Consejería de Sanidad de la Comunidad y Madrid; 2008.

17. Liberona Y, Castillo O, Rozowski J. Suficiencia de la dieta y composición corporal en un grupo de niños de 11-14 años de dos clubes deportivos en Santiago de Chile. Rev Chil Nutr 2010;37:145-54.

18. Keller KL, et al. Increased sweetened beverage intake is associated with reduced milk and calcium intake in 3- to 7-year-old children at multi-item laboratory lunches. J Am Diet Assoc 2009;109(3):497-501.

19. Darmon N, Drewnowski A. Does social class predict diet quality? Am J Clin Nutr 2008;87(5):1107-17.

20. Vergnaud AC, Norat T, Romanguero ND, Mouw T, et al. Fruit and vegetable consumption and prospective weight change in participants of the european prospective investigation into cancer and nutrition-physical activity, nutrition, alcohol, cessation of smoking, eating out of home, and obesity study. Am J Clin Nutr 2012; 95(1):184-93.

21. Sebastian RS, Wilkinson Enns C, Goldman JD. US Adolescents and MyPyramid: associations between fast-food consumption and lower likelihood of meeting recommendations. J Am Diet Assoc 2009;109(2):226.

22. Piaggio L, et al. Alimentación infantil en el ámbito escolar: entre patios, aulas y comedores. Salud colectiva 2011;7:199213.

23. Kovalskys IC. Factores obesogénicos vinculados con el ambiente infantil. In: Crecimiento saludable. Entre la desnutrición y la obesidad en el cono sur. Uauy R.C.E, Buenos Aires: Instituto Danone, 2012.

24. Cade J, et al. Development, validation and utilisation of food-frequency questionnaires - a review. Public Health Nutr 2002;5(4):567-87.

25. Wakai K. Areview of food frequency questionnaires developed and validated in Japan. J Epidemiol 2009;19(1):1-11.

26. Rockett HR, Berkey CS, Colditz GA. Evaluation of dietary assessment instruments in adolescents. Curr Opin Clin Nutr Metab Care 2003;6(5):557-62.

27. Sidossis LS. Assessment of energy expenditure and energy intake in children: is it possible? Curr Op Clin Nutr Metab Care 2003; 6(5):499. 